\title{
The Effect of Homogenization Parameters on the Structure of EN AW-6082 Alloy
}

Jan Luštinec ${ }^{1}$, Vladivoj Očenášek ${ }^{1}$, Miroslav Jelínek jr. ${ }^{2}$

${ }^{1}$ SVÚM a.s. Tovární 2053, 25088 Čelákovice. Czech Republic. E-mail: lustinec@svum.cz, ocenasek@svum.cz ${ }^{2}$ Constellium Extrusions Děčín s.r.o. Ústecká 751/37, 40502 Děčín V-Rozbělesy. Czech Republic. E-mail: radek.vrubl@constellium.com

High temperature homogenization annealing of DC cast billets from aluminium alloys used for extrusion pressing is considered as one of substantial technological operations during extrusion processing. The structure of DC cast billets consists of dendrite cell structure and contains coarse and inhomogeneously distributed intermetallic phases of $\beta$-AlFeSi and $\alpha-\mathrm{Al}(\mathrm{Fe}, \mathrm{Mn}) \mathrm{Si}$ type.Structure after a homogenization annealing is quite decisive for both the final properties of extrusions and the extrudability of the cast structure. The present paper deals with the medium strength heat-treatable EN AW-6082 alloy. It is investigated the effect of heating rate, time at the annealing temperature and the cooling rate of continually cast billets during the homogenization annealing on the changes of electrical conductivity, structure and intermetallic phases.

Keywords: EN AW-6082 aluminium alloy, Homogenization, Extrusion, Structure, Phases

\section{Acknowledgement}

The financial support of the Constellium Extrusions Děčín s.r.o. under project No. 3/10/2011 is gratefully acknowledged.

\section{References}

[1] SUGAWARA, T., TANIHATA, H., MATSUDA, K., IKENO, S. (1998). Effect of homogenizing treatment of AlFe-Si intermetallic phases in a 6063 aluminum alloy. In: Proc. Of The 6th Int. Conf. On aluminum Alloys, ICAA6, July 5-10, Toyohashi, Japan, pp.715.

[2] ROMETSCG, P.A., Wang, S.C. (2002). The effect of homogenizing on the quench sensitivity of 6082. In: Materials Science Forum, Vol 396 - 402, pp. 655 - 660.

[3] MRÓWKA-NOWOTNIK, G., SIENIAWSKI, J., WIERZBIŇSKA, M. (2007). Intermetallic phase particles in 6082 aluminium alloy. In: JAMME, Vol 20, Issues 1 - 2, January - February 2007.

[4] BIROL, Y. (2013). Precipitation during homogenization cooling in AlMgSi alloys. In: Transactions of Nonferrous Metals Society of China, Vol 23, Issue 7, pp. 1875 - 1881.

[5] WOŹNICKI, A., LEŚNIAK, D., WLOCH, G., LESZCZYŃSKA-MADEJ, B. WOJTYNA, A. (2015). The effect of homogenization conditions on the structure and properties of 6082 alloy billets. In: Archives of Metallurgy and Materials, Vol 60, Issue 3A, pp. $1763-1771$.

[6] HIRSCH, J. (2006). Virtual Fabrication of Aluminium Products, pp. 75. Wiley-VCH Verlag GmbH\& Co. KGaA, Weinheim.

[7] OČENÁŠEK, V., SEDLÁČEK, P., JELÍNEK, M. (2007). Homogenisation impact on structure and properties of AA6082 die forgings made from extruded rods. In: 5th Int. Conference "Aluminium 2007", 10. - 12. 10. 2007, Staré Splavy, Czech Republic.

[8] KOVALČÍK, T., STOULIL, J., SLÁMA, P., VOJTĚCH, D. (2015). The influence of heat treatment on mechanical and corrosion properties of wrought aluminium alloys 2024 and 6064. In: Manufacturing Technology, Vol. 15, Issue 1 , pp. $54-61$.

[9] FURU, T., VANTE, H.E. (2000). Grain structure control of flat extruded AA6082 alloy. In: Materials Science Forum, Vol 331 - 337 II, pp. $843-848$.

[10] LUŠTINEC, J., OČENÁŠEK, V., JELÍNEK, M. (2016). Structure of Al-Mg-Si cast and extruded rods for die forgings. In: Manufacturing technology, Vol 16, Issue 5, pp. 1009 - 1013.

[11] MORAVEC, J., NOVÁKOVÁ, I. BRADAČ, J. (2016). Effect of age hardening conditions on mechanical properties of AW 6082 alloy welds. In: Manufacturing technology, Vol 16, Issue 1, pp. 192 - 198. 